\title{
Fenoxapro-P-Ethyl Induced Biochemical Changes in Fresh Water Fish Cyprinus carpio under Sublethal Exposure
}

\author{
Srinivas B Neglur ${ }^{1}$, Rajeshwari D. Sanakal ${ }^{2 *}$, Muniswamy David ${ }^{1}$
}

${ }^{\mathrm{T}}$ Environmental Biology and Molecular Toxicology Laboratory Department of P.G.Studies in Zoology Karnatak University Dharwad580003 Karnataka, India

${ }^{2}$ Department of Zoology, Karnatak Science College, Dharwad 580001, Karnataka, India

\begin{tabular}{|c|c|}
\hline $\begin{array}{c}\text { Article History } \\
\text { Received: } 26.11 .2021 \\
\text { Accepted: } 01.01 .2022 \\
\text { Published: } 08.01 .2022 \\
\text { Journal homepage: } \\
\text { http://www.easpublisher.com }\end{array}$ & $\begin{array}{l}\text { Abstract: Fenoxapro-P-Ethyl is an herbicide which has wide scope of uses in } \\
\text { agrarian fields to control weeds. The used Fenoxapro-P-Ethyl part is let off into } \\
\text { streams which definitely influences the endurance of the fish. In the current } \\
\text { investigation an endeavor was made to dissect the harmfulness of Fenoxapro-P- } \\
\text { Ethyl and Freshwater fish, C. carpio were exposed to sublethal concentration } \\
(37.5 \mu \mathrm{g} / \mathrm{L}) \text { of Fenoxapro-P-Ethyl for } 15,30 \text { and } 45 \text { days to analyze various } \\
\text { parameters of protein metabolism in functionally different tissues. Total, structural } \\
\text { and soluble proteins showed decrement; whereas free amino acids and the activities } \\
\text { of protease, aspartate aminotransferase and alanine aminotransferase significantly } \\
\text { increased in Fenoxapro-P-Ethyl exposed fish. Interestingly, ammonia content } \\
\text { decreased but urea and glutamine increased at all periods of exposure. It was also } \\
\text { observed that alterations steadily increased with the period of exposure and } \\
\text { exhibited tissue specificity. Thus variation in the protein metabolism of the fish } \\
\text { exposed to Fenoxapro-P-Ethyl indicates its toxic effect on the cellular metabolism } \\
\text { thereby leading to impaired protein synthetic machinery. In light of the result of the } \\
\text { current examination, it is along these lines recommended that proper measures be } \\
\text { taken for detoxification of Fenoxapro-P-Ethyl before it is released in to streams, as } \\
\text { it can bargain the endurance of aquatic territory subsequently bringing about the } \\
\text { unsettling influences of aquatic biological system. } \\
\text { Keywords: Fenoxapro-P-Ethyl toxicity; Protein metabolism; } C \text {. carpio. }\end{array}$ \\
\hline & \\
\hline
\end{tabular}

\section{INTRODUCTION}

Worldwide pesticide use has increased dramatically over the past two decades (Hosetti. B. B et al 2011). Pesticides have become some of the most frequently occurring organic pollutants of agricultural soils and ground and surface waters (Moore, S et al., 1954), causing ecological imbalances that may have toxicological effects on natural ecosystems, especially aquatic systems(Ghosh, D et al., 2006) (Magar. R. S et al., 2013). They cause damage to non-target organisms, including fish. In aquatic toxicology studies, fish are important indicators of the impact of toxic substances. The potential effects of pesticide use on human health, ecosystems, and the environment is of great interest (Harper, H.A et al., 1979).

Fenoxapro-P-Ethyl, chemically known as (R)2-[4-(6-chlorobenzoxazol-2-yloxy) phenoxy]propionic acid ethyl ester (Scheme), is used as a herbicide and belongs to the class of aryloxyphenoxypropionates.
Members of this class are considered selective and systematic herbicides. They are absorbed by plants to interfere with the production of fatty acids by inhibition of acetyl coenzyme-A carboxylase, which is needed for plant growth. These herbicides are used to inhibit the growth of unwanted annual and perennial grasses between crops including barley, soybean, wheat, wild oat, tomato, cotton, and potato. Since the Environmental Protection Agency and Cancer Assessment Review Committee (CARC) classified these chemicals as carcinogenic to humans, the determination of their concentration levels in crops and environmental samples is of great importance.

This has resulted in its discharge into the aquatic environment and consequently several laboratory studies have been performed, which evidenced that Fenoxapro-P-Ethyl is extremely toxic to fish at concentrations with $96 \mathrm{~h} \mathrm{LC}_{50} 300 \mu \mathrm{g} / \mathrm{L}$ in the range of $37.5 \mu \mathrm{g} / \mathrm{L}$. A few experiments were carried out

*Corresponding Author: Dr. (smt) Rajeshwari D. Sanakal Environmental Biology and Molecular Toxicology Laboratory Department of P.G.Studies in Zoology Karnatak University Dharwad-580003 
earlier to evaluate precisely the action potential of cypermethrin on AChE and ATPase systems and on certain biochemical parameters in Cyprinus carpio (Jebakumar, S.R.D et al., 1990). Ravi Shankar et al. (1992) also studied the effect of cypermethrin on glycogen and lipid contents of freshwater fish, Lepidocephalichthys thermalis (A. Rebich et al., 2004). Present study critically examines the magnitude and relationships of the metabolites and enzymes involved in the metabolism of proteins in functionally different tissues of C. carpio treated with sublethal concentration of Fenoxapro-P-Ethyl.

\section{MATERIALS AND MethodS}

Collection and maintenance of fish

Healthy $C$. carpio were procured from the State Fisheries Department, Hospet, India and were acclimatized to laboratory conditions for $20 \mathrm{~d}$ at $25^{\circ} \mathrm{C}$. Further they were held in dechlorinated tap water in large cement tanks which was previously washed with potassium permanganate to free the walls from any microbial growth. Fish were fed regularly and 12-16 h of photoperiod daily during acclimation. Water was renewed daily, whose physico-chemical characteristics were analyzed following the methods mentioned in APHA and were found as follows, temperature, $25 \pm 4$

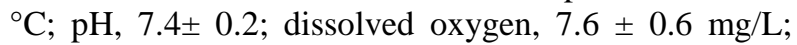
total hardness, $30.2 \pm 2.1 \mathrm{mg}$ as $\mathrm{CaCO} 3 / \mathrm{L}$; salinity, nil; specific gravity, 1.003; conductivity less than $12 \mu \mathrm{S} / \mathrm{cm}$; calcium, $15.86 \pm 0.92 \mathrm{mg} / \mathrm{L}$; phosphate, $0.2 \pm 0.004$ $\mu \mathrm{g} / \mathrm{L}$ and magnesium, $0.6 \pm 0.3 \mathrm{mg} / \mathrm{L}[14]$.

\section{Preparation of stock}

Fenoxapro-P-Ethyl of $6.9 \%$ w/v EC was procured from Bayer house, Central Avenue, Hiranandani estate (west), India. Stock solution was prepared by dissolving Fenoxapro-P-Ethyl in double distilled water in a standard volumetric flask. Water was renewed every day over test periods. Henceforth, the replacement of the water medium was followed by the addition of the desired dose of the test compound. The fish were exposed in batches of 10 to a fixed concentration of Fenoxapro-P-Ethyl with $20 \mathrm{~L}$ of water in three replicates for each concentration. One eighth $(37.5 \mathrm{mg} / \mathrm{L})$ of the $\mathrm{LC}_{50}(300 \mathrm{mg} / \mathrm{L})$ David M.\& Lokeshkumar P 2020 was selected as sub lethal concentration for studies and the duration of exposure were 15, 30 and 45 days Srinivas B Neglur et al., 2021. This study was conducted under OECD Guideline for static renewal test conditions OECD 1992. At the end of 15,30 and 45 days, fish were sacrificed and were sampled for biochemical studies.

\section{Biochemical studies}

\section{Estimation of soluble, structural and total proteins}

The soluble, structural and the total proteins in the gills, muscles and liver were estimated using the folin-phenol reagent method as described by Lowary.
O. H, et al. 1951. 1\% homogenate (W/V) was prepared in an ice-cold 0.25 M sucrose solution. For soluble and structural proteins, $1.0 \mathrm{~mL}$ of the homogenate was taken and centrifuged at $3000 \mathrm{rpm}$ for $10 \mathrm{~min}$. The supernatant was separated and to both the supernatant and residue, $3 \mathrm{~mL}$ of $10 \%$ trichloroacetic acid (TCA) was added and again centrifuged at $3000 \mathrm{rpm}$. The supernatants were discarded and the residues were taken for experimentation. For total proteins, $1 \mathrm{~mL}$ of homogenate was taken; to it $3 \mathrm{~mL}$ of $10 \%$ TCA was added and centrifuged at $3000 \mathrm{rpm}$. The supernatant was discarded and the residue was taken for experimentation. All three residues were dissolved in 5 $\mathrm{mL}$ of $0.1 \mathrm{~N}$ sodium hydroxide and to $1 \mathrm{~mL}$ of each of these solutions, $4 \mathrm{~mL}$ of reagent $-\mathrm{D}$ (mixture of $2 \%$ sodium carbonate and $0.5 \%$ copper sulphate in 50:1 ratio) was added. The samples were allowed to stand for $10 \mathrm{~min}$, at the end of which $0.4 \mathrm{~mL}$ of folin-phenol reagent (diluted with double distilled water in 1:1 ratio before use) was added. Finally, the optical density of the colour developed was measured using a spectrophotometer (Secomam, Anthelie advanced 2) at a wavelength of $600 \mathrm{~nm}$.

\section{Estimation of Free amino acid and Glutamine}

Free amino acid level in the gills, muscles and liver was estimated by the ninhydrin method as described by Moore and Stein. 5\% organ homogenates (W/V) were prepared in $10 \%$ TCA and centrifuged at $2000 \mathrm{rpm}$ for $15 \mathrm{~min}$. To $0.2 \mathrm{~mL}$ of supernatant, $2.0 \mathrm{~mL}$ of ninhydrin reagent was added and the contents were boiled for exactly $5 \mathrm{~min}$. They were cooled under tap water and the volume was made to $10 \mathrm{~mL}$ with distilled water. The optical density of the color developed was measured using a spectrophotometer at a wavelength of $570 \mathrm{~nm}$. A blank using distilled water and amino acid standards were also run similarly. The free amino acid levels are expressed as $\mathrm{mg}$ amino acid nitrogen released/g wet wt. of the liver.

\section{Estimation of protease activity}

Protease activity in the gills, muscles and liver was estimated using the ninhydrin method as described by Davis. N.C, et al., 1955. 1\% homogenate (W/V) was prepared in distilled water. To $2.0 \mathrm{~mL}$ of homogenate $0.5 \mathrm{~mL}$ of $1 \%$ casein and $2.0 \mathrm{~mL}$ of $0.1 \mathrm{M}$ phosphate buffer ( $\mathrm{pH}$ 5.0) were added. The contents were mixed well and incubated at $30^{\circ} \mathrm{C}$ for $30 \mathrm{~min}$. The reaction was stopped by adding $2 \mathrm{~mL}$ of $2 \%$ ninhydrin reagent. Again the contents were mixed thoroughly and placed in a boiling water bath for $20 \mathrm{~min}$. The solution was cooled and made to $10 \mathrm{~mL}$ with diluents (distilled water and n-propanol in 1:1 ratio). The optical density of the colour developed was measured using spectrophotometer at a wavelength of $570 \mathrm{~nm}$. A blank taking $2.0 \mathrm{~mL}$ of distilled water and a control taking 2.0 $\mathrm{mL}$ of boiled enzyme were also run similarly. Amino acid standards were prepared alongside for comparison. The protease activity is expressed as $\mu$ moles amino acid nitrogen released/mg protein/h. 


\section{Assay of enzymes}

Five percent homogenate of the tissues were prepared in $0.25 \mathrm{M}$ ice cold sucrose solution for aspartate aminotransferase (AAT) and alanine aminotransferase (ALAT); in ice cold distilled water for protease and these were centrifuged at $2500 \mathrm{rpm}$ for 10 min in a refrigerated centrifuge at $4 \mathrm{C}$ to remove cell debris and clear cell free extracts were used as enzyme source. Protease activity was measured (Moore et al., 1954) with the reaction mixture containing $100 \mathrm{~lm}$ of phosphate buffer ( $\mathrm{pH} 7.0)$ and $12 \mathrm{mg}$ of denatured protein. AAT (E.C. 2.6.1.1) and ALAT (E.C. 2.6.1.2) activities were assayed following the method of [37]. The incubation mixture for AAT contain $100 \mathrm{~lm}$ of phosphate buffer (pH 7.4), $2 \mathrm{~lm}$ of ketoglutarate and 50 lm of L-aspartic acid ( $\mathrm{pH}$ 7.4). For ALAT, incubation steps followed are the same as described for AAT except for the substrate used was D-alanine $(50 \mathrm{~lm})$. The standard graph was prepared with sodium pyruvate. All spectrophotometric measurements were determined using Baush and Lomb spectronic 20.

\section{Evaluation of results}

Average of six individual estimations were taken after pooling them and the mean values of control and experimental fishes were subjected to statistical treatment using one-way analysis of variance (ANOVA). If the difference between control and experimental values exceeds the critical difference (CD), the values were considered as significant at 5\% level.

\section{Ethical statement}

All the experiments performed in the present study abide by the guidelines of the Institutional Animal Ethics Committee (IAEC). The experimental animals used in the study were handled with care according to the guidelines provided by the Committee for the Purpose of Control and Supervision of Experiments on Animals (CPCSEA), New Delhi, India.

\section{RESUlTS}

\section{Effect on levels of TP, SP and StP}

During sub-acute exposure to Fenoxapro-PEthyl, the TP, SP and StP contents decreased in all the tissues at all periods of exposure (Table 1). Decrement of all the protein fractions was maximum in liver followed by gill and muscle. Comparison of different protein fractions at different exposure reveals that exposure 30 and 45 days was affected to greater extent and 15 days was the least.

\section{Effect on FAA and protease activity}

Increase in FAA was noticed in all the tissues of Fenoxapro-P-Ethyl -exposed fish (Table 1). Liver exhibited more elevation of FAA levels when compared to other tissues at all the exposures (Table 2). Among the control group liver showed highest enzyme activity. This increment was consistent with increase in exposure periods. Significant alterations were noticed at all periods except in the liver tissue of fish exposed for 45 days.

\section{Effect on AAT and ALAT activities}

Fish exhibited significantly higher AAT and ALAT activities in all the tissues during Fenoxapro-PEthyl toxicity (Table 2). The increment of ALAT in gills, muscle and liver at 30 and 45 days exposures was insignificant. Activity of ALAT and its increment was more when compared to AAT in all the tissues.

\section{Effect on ammonia, urea and glutamine level}

Ammonia level was decreased in the tissues of C. carpio exposed to Fenoxapro-P-Ethyl (Table 3). Decrement of ammonia was significant in all the tissues and at all time points tested; an exception was in liver at 45 days of exposure. Contrast to this, levels of urea and glutamine showed an increasing trend (Table 3). Increment of glutamine was more when compared to urea. Changes in both these nitrogenous excretory products were significant in all the exposures except urea at 15, 30 and 45 days exposure in muscles.

Table-1: Quantity of Fenoxapro-P-Ethyl ( $\mu \mathrm{g} / \mathrm{g}$ wet wt) accumulated in the organs of the fish, Cyprinus carpio on the exposure to sub lethal concentration of Fenoxapro-P-Ethyl.

\begin{tabular}{|c|c|c|c|c|}
\hline \multirow[t]{2}{*}{ Tissue } & \multirow[t]{2}{*}{ Control } & \multicolumn{3}{|c|}{ Sub lethal Exposure Periods (Days) } \\
\hline & & 15 & 30 & 45 \\
\hline $\begin{array}{l}\text { Total Protein } \\
\text { Gills } \\
\pm \mathrm{SD} \\
\% \text { Change }\end{array}$ & $\begin{array}{l}69.43^{C} \\
0.0002 \\
-\cdots---\end{array}$ & $\begin{array}{l}67.59^{\mathrm{D}} \\
0.0003 \\
-2.65\end{array}$ & $\begin{array}{l}75.99^{\mathrm{B}} \\
0.0003 \\
-\mathbf{9 . 4 4}\end{array}$ & $\begin{array}{l}81.93^{\mathrm{A}} \\
0.0003 \\
-17.99\end{array}$ \\
\hline $\begin{array}{l}\text { Muscles } \\
\pm \text { SD } \\
\% \text { Change }\end{array}$ & $\begin{array}{l}101.52^{C} \\
0.0004 \\
----\end{array}$ & $\begin{array}{l}80.09^{D} \\
0.0004 \\
-21.10\end{array}$ & $\begin{array}{l}110.63^{B} \\
0.0003 \\
-8.96\end{array}$ & $\begin{array}{l}117.52^{A} \\
0.0003 \\
-15.75\end{array}$ \\
\hline $\begin{array}{l}\text { Liver } \\
\pm \mathrm{SD} \\
\% \text { Change } \\
\end{array}$ & $\begin{array}{l}127.31^{\mathrm{C}} \\
0.0002 \\
------ \\
\end{array}$ & $\begin{array}{l}120.85^{\mathrm{D}} \\
0.0003 \\
-5.07\end{array}$ & $\begin{array}{l}132.54^{B} \\
0.0003 \\
-4.10 \\
\end{array}$ & $\begin{array}{l}147.51^{A} \\
0.0003 \\
-15.86\end{array}$ \\
\hline $\begin{array}{l}\text { Structural Protein } \\
\text { Gills } \\
\pm \text { SD } \\
\% \text { Change }\end{array}$ & $\begin{array}{l}43.97^{\mathrm{C}} \\
\mathbf{0 . 0 0 0 3} \\
---\end{array}$ & $\begin{array}{l}42.71^{\mathrm{D}} \\
0.0003 \\
-2.84\end{array}$ & $\begin{array}{l}46.71^{\mathrm{B}} \\
0.0004 \\
-6.22\end{array}$ & $\begin{array}{l}49.13^{\mathrm{A}} \\
0.0003 \\
-12.13\end{array}$ \\
\hline
\end{tabular}


Srinivas B Neglur et al, East African Scholars J Agri Life Sci; Vol-5, Iss-1 Jan, 2022): 1-9.

\begin{tabular}{|c|c|c|c|c|}
\hline $\begin{array}{l}\text { Muscles } \\
\pm \mathrm{SD} \\
\% \text { Change }\end{array}$ & $\begin{array}{l}43.97^{\mathrm{D}} \\
0.0003 \\
-\cdots- \\
\end{array}$ & $\begin{array}{l}51.68^{C} \\
0.0003 \\
-12.99 \\
\end{array}$ & $\begin{array}{l}66.13^{B} \\
0.0003 \\
-11.34\end{array}$ & $\begin{array}{l}68.95^{\mathrm{A}} \\
0.0004 \\
-16.09\end{array}$ \\
\hline $\begin{array}{l}\text { Liver } \\
\pm \text { SD } \\
\% \text { Change }\end{array}$ & $\begin{array}{l}68.39^{C} \\
0.0003 \\
-\cdots--\end{array}$ & $\begin{array}{l}66.98^{\mathrm{D}} \\
\mathbf{0 . 0 0 4 0} \\
-2.002\end{array}$ & $\begin{array}{l}72.22^{\mathrm{B}} \\
0.0040 \\
-4.13\end{array}$ & $\begin{array}{l}79.82^{\mathrm{A}} \\
0.0003 \\
-16.70\end{array}$ \\
\hline $\begin{array}{l}\text { Soluble Protein } \\
\text { Gills } \\
\pm \text { SD } \\
\% \text { Change }\end{array}$ & $\begin{array}{l}26.29^{D} \\
0.4083 \\
-\cdots--\end{array}$ & $\begin{array}{l}24.86^{C} \\
0.0034 \\
-5.42 \\
\end{array}$ & $\begin{array}{l}29.28^{B} \\
0.0003 \\
-11.36\end{array}$ & $\begin{array}{l}32.62^{\mathrm{A}} \\
0.0003 \\
-24.05\end{array}$ \\
\hline $\begin{array}{l}\text { Muscles } \\
\pm \text { SD } \\
\% \text { Change }\end{array}$ & $\begin{array}{l}42.12^{\mathrm{C}} \\
0.0003 \\
----\end{array}$ & $\begin{array}{l}20.41^{\mathrm{D}} \\
0.0003 \\
-51.53\end{array}$ & $\begin{array}{l}44.49^{B} \\
0.0003 \\
-5.62\end{array}$ & $\begin{array}{l}48.56^{A} \\
0.0003 \\
-24.05\end{array}$ \\
\hline $\begin{array}{l}\text { Liver } \\
\pm \text { SD } \\
\% \text { Change }\end{array}$ & $\begin{array}{l}58.91^{B} \\
0.0003 \\
-\cdots---\end{array}$ & $\begin{array}{l}\mathbf{5 3 . 8 6} \\
0.0034 \\
-3.76\end{array}$ & $\begin{array}{l}60.31^{\mathrm{A}} \\
0.0003 \\
-16.17\end{array}$ & $\begin{array}{l}67.69^{\mathrm{C}} \\
0.0003 \\
-14.90\end{array}$ \\
\hline $\begin{array}{l}\text { Free Amino acids } \\
\text { Gills } \\
\pm \mathrm{SD} \\
\% \text { Change }\end{array}$ & $\begin{array}{l}12.51^{\mathrm{D}} \\
\mathbf{0 . 0 0 0 4} \\
-\cdots--\end{array}$ & $\begin{array}{l}15.30^{A} \\
0.0040 \\
-35.43\end{array}$ & $\begin{array}{l}13.97^{\mathrm{C}} \\
0.0003 \\
-11.70\end{array}$ & $\begin{array}{l}14.42^{\mathrm{B}} \\
0.0003 \\
-15.29\end{array}$ \\
\hline $\begin{array}{l}\text { Muscles } \\
\pm \mathrm{SD} \\
\% \text { Change }\end{array}$ & $\begin{array}{l}26.28^{D} \\
0.0040 \\
--- \\
\end{array}$ & $\begin{array}{l}28.43^{C} \\
0.0243 \\
-8.17 \\
\end{array}$ & $\begin{array}{l}29.76^{B} \\
0.0003 \\
-13.23 \\
\end{array}$ & $\begin{array}{l}30.00^{A} \\
0.0003 \\
-14.16 \\
\end{array}$ \\
\hline $\begin{array}{l}\text { Liver } \\
\pm \text { SD } \\
\% \text { Change }\end{array}$ & $\begin{array}{l}36.65^{\mathrm{C}} \\
1.5326 \\
---- \\
\end{array}$ & $\begin{array}{l}34.70^{D} \\
0.2585 \\
-5.31 \\
\end{array}$ & $\begin{array}{l}37.84^{\mathrm{B}} \\
0.0003 \\
-3.23 \\
\end{array}$ & $\begin{array}{l}41.31^{\mathrm{A}} \\
0.0003 \\
-12.69\end{array}$ \\
\hline
\end{tabular}

Means are $\pm \mathrm{SD}(\mathrm{n}=6)$ for a tissue in a column followed by the same letter are not significantly different $(\mathrm{P} \leq 0.01)$ from each other according to One way ANOVA.

Table-2: Enzymological changes in different tissues of fish, Cyprinus carpio exposed to Fenoxapro-P-Ethyl

\begin{tabular}{|c|c|c|c|c|}
\hline \multirow[t]{2}{*}{ Tissues } & \multirow[t]{2}{*}{ Control } & \multicolumn{3}{|c|}{ Sublethal Exposure periods in Days } \\
\hline & & 15 & 30 & 45 \\
\hline $\begin{array}{l}\text { Protease Activity } \\
\text { Gills } \\
\pm \text { SD } \\
\% \text { Change }\end{array}$ & $\begin{array}{l}\mathbf{0 . 5 0 ^ { \mathrm { B } }} \\
\mathbf{0 . 0 0 0 3} \\
----\end{array}$ & $\begin{array}{l}0.69^{A} \\
0.0004 \\
-37.11\end{array}$ & $\begin{array}{l}0.70^{\mathrm{D}} \\
0.0003 \\
-39.38\end{array}$ & $\begin{array}{l}0.77^{\mathrm{C}} \\
\mathbf{0 . 0 0 3 4} \\
-\mathbf{5 3 . 6 0}\end{array}$ \\
\hline $\begin{array}{l}\text { Muscles } \\
\pm \text { SD } \\
\% \text { Change } \\
\end{array}$ & $\begin{array}{l}0.13^{\mathrm{C}} \\
0.0003 \\
---- \\
\end{array}$ & $\begin{array}{l}0.84^{B} \\
0.0004 \\
-509.25 \\
\end{array}$ & $\begin{array}{l}\mathbf{0 . 8 8} \\
\mathbf{0 . 0 0 3 7} \\
-542.08 \\
\end{array}$ & $\begin{array}{l}0.90^{A} \\
0.0034 \\
-551.84 \\
\end{array}$ \\
\hline $\begin{array}{l}\text { Liver } \\
\pm \mathrm{SD} \\
\% \text { Change } \\
\end{array}$ & $\begin{array}{l}0.82^{\mathrm{D}} \\
0.0003 \\
---- \\
\end{array}$ & $\begin{array}{l}0.90^{\mathrm{B}} \\
0.0003 \\
-9.87 \\
\end{array}$ & $\begin{array}{l}0.84^{\mathrm{C}} \\
0.2451 \\
-2.67 \\
\end{array}$ & \begin{tabular}{l|l|}
$0.98^{\mathrm{A}}$ \\
0.0003 \\
-19.72 \\
\end{tabular} \\
\hline $\begin{array}{l}\text { AAT } \\
\text { Gills } \\
\pm \text { SD } \\
\% \text { Change }\end{array}$ & \begin{tabular}{l}
$3.36^{\mathrm{B}}$ \\
$\mathbf{0 . 0 0 0 4}$ \\
\hdashline-- \\
\end{tabular} & $\begin{array}{l}3.54^{\mathrm{D}} \\
\mathbf{0 . 0 0 0 3} \\
\mathbf{- 5 . 2 5}\end{array}$ & $\begin{array}{l}3.59^{\mathrm{C}} \\
0.0003 \\
-6.74\end{array}$ & $\begin{array}{l}3.84^{\mathrm{A}} \\
0.0003 \\
-14.16 \\
\end{array}$ \\
\hline $\begin{array}{l}\text { Muscles } \\
\pm \text { SD } \\
\% \text { Change } \\
\end{array}$ & $\begin{array}{l}4.07^{\mathrm{D}} \\
\mathbf{0 . 0 0 0 3} \\
--- \\
\end{array}$ & $\begin{array}{l}4.83^{\mathrm{C}} \\
0.0003 \\
-18.54 \\
\end{array}$ & $\begin{array}{l}4.92^{\mathrm{B}} \\
0.0003 \\
-20.82 \\
\end{array}$ & $\begin{array}{l}5.08^{\mathrm{A}} \\
0.0004 \\
-24.65 \\
\end{array}$ \\
\hline $\begin{array}{l}\text { Liver } \\
\pm \mathrm{SD} \\
\% \text { Change } \\
\end{array}$ & $\begin{array}{l}4.60^{D} \\
0.0003 \\
-\cdots \\
\end{array}$ & $\begin{array}{l}5.36^{\mathrm{C}} \\
0.0003 \\
-16.46 \\
\end{array}$ & $\begin{array}{l}5.49^{\mathrm{B}} \\
0.0003 \\
-19.28 \\
\end{array}$ & \begin{tabular}{l|l|}
$6.61^{A}$ \\
0.0004 \\
-43.71 \\
\end{tabular} \\
\hline $\begin{array}{l}\text { ALAT } \\
\text { Gills } \\
\pm \text { SD } \\
\% \text { Change }\end{array}$ & \begin{tabular}{l}
$3.43^{\mathrm{D}}$ \\
$\mathbf{0 . 0 0 0 3}$ \\
\hdashline-- \\
\end{tabular} & $\begin{array}{l}3.88^{\mathrm{C}} \\
0.0040 \\
-13.23 \\
\end{array}$ & $\begin{array}{l}4.50^{B} \\
0.0003 \\
-31.18 \\
\end{array}$ & $\begin{array}{l}4.73^{\mathrm{A}} \\
0.0003 \\
-38.05 \\
\end{array}$ \\
\hline $\begin{array}{l}\text { Muscles } \\
\pm \mathrm{SD} \\
\% \text { Change }\end{array}$ & $\begin{array}{l}7.13^{\mathrm{C}} \\
0.0003 \\
---- \\
\end{array}$ & $\begin{array}{l}\mathbf{7 . 8 4 ^ { \mathrm { B } }} \\
\mathbf{0 . 0 0 0 3} \\
-9.98 \\
\end{array}$ & \begin{tabular}{l|}
$7.91^{\mathrm{D}}$ \\
0.0003 \\
-10.98 \\
\end{tabular} & $\begin{array}{l}8.01^{\mathrm{A}} \\
0.0003 \\
-12.40 \\
\end{array}$ \\
\hline $\begin{array}{l}\text { Liver } \\
\pm \mathrm{SD} \\
\% \text { Change }\end{array}$ & $\begin{array}{l}9.12^{\mathrm{D}} \\
0.0004 \\
----- \\
\end{array}$ & $\begin{array}{c}10.22^{\mathrm{C}} \\
0.0034 \\
-12.05 \\
\end{array}$ & $\begin{array}{l}10.60^{\mathrm{B}} \\
\mathbf{0 . 0 0 3 4} \\
-16.23 \\
\end{array}$ & $\begin{array}{l}10.89^{A} \\
0.0003 \\
-19.38 \\
\end{array}$ \\
\hline
\end{tabular}

Means are $\pm \mathrm{SD}(\mathrm{n}=6)$ for a tissue in a column followed by the same letter are not significantly different $(\mathrm{P} \leq 0.01)$ from each other according to one way ANOVA. 
Table-3: Biochemical changes in different tissues of fish, Cyprinus carpio exposed to Fenoxapro-P-Ethyl

\begin{tabular}{|c|c|c|c|c|}
\hline \multirow[t]{2}{*}{ Tissues } & \multirow[t]{2}{*}{ Control } & \multicolumn{3}{|c|}{ Sub lethal Exposure periods in Days } \\
\hline & & 15 & 30 & 45 \\
\hline $\begin{array}{l}\text { Ammonia } \\
\text { Gills } \\
\pm \text { SD } \\
\% \text { Change }\end{array}$ & $\begin{array}{l}3.72^{\mathrm{A}} \\
0.0003 \\
-.--\end{array}$ & $\begin{array}{l}2.04^{\mathrm{C}} \\
0.0040 \\
-45.14\end{array}$ & $\begin{array}{l}1.40^{D} \\
0.0003 \\
-62.41\end{array}$ & $\begin{array}{l}2.36^{B} \\
0.0956 \\
-36.56\end{array}$ \\
\hline $\begin{array}{l}\text { Muscles } \\
\pm \mathrm{SD} \\
\% \text { Change }\end{array}$ & $\begin{array}{l}5.65^{\mathrm{B}} \\
0.0003 \\
---\end{array}$ & $\begin{array}{l}3.65^{\mathrm{C}} \\
0.0002 \\
-88.37\end{array}$ & $\begin{array}{l}2.12^{D} \\
0.0002 \\
-62.37\end{array}$ & $\begin{array}{l}8.09^{A} \\
0.0002 \\
-43.09\end{array}$ \\
\hline $\begin{array}{l}\text { Liver } \\
\pm \text { SD } \\
\% \text { Change } \\
\end{array}$ & $\begin{array}{l}27.16^{\mathrm{B}} \\
0.0002 \\
----\end{array}$ & $\begin{array}{l}21.33^{D} \\
0.0002 \\
-21.48 \\
\end{array}$ & $\begin{array}{l}22.62^{C} \\
0.0002 \\
-16.73\end{array}$ & $\begin{array}{l}43.59^{A} \\
0.0002 \\
-60.46 \\
\end{array}$ \\
\hline $\begin{array}{l}\text { Urea levels } \\
\text { Gills } \\
\pm \text { SD } \\
\% \text { Change }\end{array}$ & $\begin{array}{l}0.67^{\mathrm{C}} \\
\mathbf{0 . 0 0 8 4} \\
---- \\
\end{array}$ & $\begin{array}{l}0.73^{\mathrm{A}} \\
0.0003 \\
-9.61 \\
\end{array}$ & $\begin{array}{l}0.70^{B} \\
0.0003 \\
-5.56 \\
\end{array}$ & $\begin{array}{l}0.70^{D} \\
0.0028 \\
-5.02 \\
\end{array}$ \\
\hline $\begin{array}{l}\text { Muscles } \\
\pm \text { SD } \\
\% \text { Change }\end{array}$ & $\begin{array}{l}0.78^{\mathrm{D}} \\
0.0003 \\
--.\end{array}$ & $\begin{array}{l}0.89^{A} \\
0.0003 \\
-15.08\end{array}$ & $\begin{array}{l}0.84^{B} \\
0.0003 \\
-8.04\end{array}$ & $\begin{array}{l}0.81^{\mathrm{C}} \\
0.0043 \\
-4.45\end{array}$ \\
\hline $\begin{array}{l}\text { Liver } \\
\pm \mathrm{SD} \\
\% \text { Change } \\
\end{array}$ & $\begin{array}{l}2.32^{\mathrm{D}} \\
0.0004 \\
----\end{array}$ & $\begin{array}{l}2.88^{\mathrm{A}} \\
0.0003 \\
-23.71 \\
\end{array}$ & $\begin{array}{l}2.58^{C} \\
0.0003 \\
-10.99 \\
\end{array}$ & $\begin{array}{l}2.85^{\mathrm{B}} \\
0.0003 \\
-22.58 \\
\end{array}$ \\
\hline $\begin{array}{l}\text { Glutamine levels } \\
\text { Gills } \\
\pm \text { SD } \\
\% \text { Change }\end{array}$ & $\begin{array}{l}5.81^{D} \\
0.0027 \\
----\end{array}$ & $\begin{array}{l}8.31^{A} \\
0.0004 \\
-43.01\end{array}$ & $\begin{array}{l}7.96^{B} \\
0.0004 \\
-36.94\end{array}$ & $\begin{array}{l}7.53^{C} \\
0.0003 \\
-29.59\end{array}$ \\
\hline $\begin{array}{l}\text { Muscles } \\
\pm \text { SD } \\
\% \text { Change }\end{array}$ & $\begin{array}{l}7.11^{D} \\
0.0004 \\
-.-\end{array}$ & $\begin{array}{l}9.22^{\mathrm{A}} \\
0.0003 \\
-29.61\end{array}$ & $\begin{array}{l}8.84^{B} \\
0.0002 \\
-24.29\end{array}$ & $\begin{array}{l}8.00^{C} \\
0.0003 \\
-12.56\end{array}$ \\
\hline $\begin{array}{l}\text { Liver } \\
\pm \mathrm{SD} \\
\% \text { Change }\end{array}$ & $\begin{array}{l}30.60^{\mathrm{D}} \\
0.0003 \\
----\end{array}$ & $\begin{array}{c}35.01^{\mathrm{A}} \\
0.0003 \\
-14.40 \\
\end{array}$ & $\begin{array}{l}31.85^{\mathrm{B}} \\
0.4084 \\
-4.0752 \\
\end{array}$ & $\begin{array}{l}31.70^{\mathrm{C}} \\
0.0003 \\
-3.59 \\
\end{array}$ \\
\hline
\end{tabular}

Means are \pm SD $(n=6)$ for a tissue in a column followed by the same letter are not significantly different $(\mathrm{P} \leq 0.01)$ from each other according to one way ANOVA.

\section{DISCUSSION}

Proteins being engaged with the physiology of the cell, they appear to involve a critical part in cell digestion. Catabolism of proteins and amino acids make a significant commitment to the absolute energy in fishes. The exhaustion of all the protein divisions seen in this investigation (Table 1) can be related to this reality. These outcomes are in concurrence with the previous report of that showed a comparable circumstance in Clarius batrachus exposed to decis Ravider V et al., 1988. Awasthi et al. Called attention to that the decreased protein substance may likewise be ascribed to the pulverization or putrefaction of cell system and resulting impedance in protein manufactured apparatus Bradbury S.P., et al., 1987. Protein consumption in tissues may establish a physiology and may assume a part of compensatory system under cypermethrin stress, to give intermediates to the Kreb's cycle. It has likewise been accounted for that this pattern of proteins was to upgrade osmolality to remunerate osmoregulatory issues experienced because of the spillage of particles and other fundamental atoms during pyrethroid harmfulness
Sambasiva Rao et al., 1983. Tissue explicit increase in protease movement (Table 2) seen at all exposures was unmistakably reflected in the breakdown of proteins. Under proteolysis, upgraded breakdown overwhelms over union. While on account of anabolic cycle, increased union disturbs the protein breakdown Harper H.A et al., 1979. Besides, histopathological harm and hydromineral unevenness during pesticide stress has been accounted for to represent the raised protease action Moorthy K.S et al., 1984.

Upgraded protease action and decreased protein level has brought about a stamped rise of FAA content in all the tissues and at unsurpassed stretches (Table 1). Probably the debasement of proteins has prompted FAA amassing. This more elevated level of FAA can likewise be ascribed to the decreased use of amino acids and is additionally reminiscent of its inclusion in the upkeep of osmotic and acid base equilibrium.

The increase and decrease of AAT and ALAT activities seen in this examination (Table 2) offers a significant help to the above pattern. This is an obvious 
sign of push of amino acids into TCA cycle through oxidative deamination and dynamic transamination. Such a marvels was important to adapt up to the energy emergency during pyrethroid stress. It has additionally been proposed that pressure conditions as a rule prompt rise in the transamination pathway Awasthi M. et al., 1984. Contribution of substitute pathways like aminotransferase responses are additionally conceivable because of restraint of oxidative proteins like succinate dehydrogenase, malate dehydrogenase, isocitrate dehydrogenase and cytochrome-c-oxidase, a circumstance likewise showed by in Labeo rohita under cypermethrin toxicity Ghosh T. K, 1989.

The most conspicuous nitrogenous excretion in teleostean fishes are alkali and urea with smelling salts in mass, a reality seen in this investigation. Ammonia, a poisonous nitrogenous finished result, is delivered exogenously into the stomach related and endogenously into the tissues through catabolism of amino acids, pyrimidines and purines Lowenstein J.M et al., 1978. Ammonia can't be put away for longer timeframe in the body as it prompts endogenous ammonotoxicity. The decrease in smelling salts content proposes that the alkali may have been changed over into non-harmful mixes, glutamine and urea, as confirmed in the current examination. Srinivas Moorthy et al., (1986) proposed that the decrease of smelling salts may likewise be because of decrease obsession of ammonia through keto acids prompting glutamate development by the activity of NADPH subordinate glutamate dehydrogenase Tilak $\mathrm{K} \mathrm{S}$ et al., 2004. Along these lines, the arrangement of urea, glutamate and glutamine by the particular compounds is by all accounts an elective pathway for the detoxification of ammonia. Further, this may likewise be ascribed to its fast dispersion into the encompassing medium. This can be upheld by the low measure of ammonia seen in gills of control fish, which fills in as the common excretory site. Prior, Cohen and Brown (1960) detailed that the union of glutamine is the significant smelling salts detoxifying component.

Increased urea levels in liver tissue may be because of initiation of urea cycle. The presence of urea in extra hepatic tissues may be because of the vascular activation and movement from liver. Additionally, decline in $\mathrm{Na}^{+}, \mathrm{K}^{+}$and $\mathrm{Ca}^{2+}$ ions in the tissues of $C$. carpio under Fenoxapro-P-Ethyl treated may likewise represent the noticed rise in urea and glutamine. It has been exhibited that both urea and glutamine remunerate the deficiency of osmolarity of the inner environment under pressure condition Sambasiva Rao et al., 1983. Hence, an increase in urea articulates by various tissues of treated fish in the height of ammonia salts other than their significant in renewing the protein nitrogen to orchestrate helpful antecedents for the support of homeostasis and active balance. Increased level of urea and glutamine under pyrethroid stress uncover that the fish, $C$. carpio may have adjusted to the biosynthesis of glutamine and urea as a significant pathway of detoxification of ammonia. Most likely this pathway might be useful to aquatic creatures particularly to fishes in detoxification and physiological remuneration or change in accordance with different exogenous and endogenous poisons.

The results from the present study indicate variations in biochemical aspects in fish exposed to $37.5 \mu \mathrm{g} / \mathrm{L} \quad\left(1 / 8 \mathrm{th}\right.$ of $\left.\mathrm{LC}_{50}\right)$ of Fenoxapro-P-Ethyl. However, no changes were observed in control group of fish. The depletion of protein levels and elevation in protease enzyme activity and that of free amino acids levels in the liver of the fish exposed to $37.5 \mu \mathrm{g} / \mathrm{L}(1 / 8 \mathrm{th}$ of $\mathrm{LC}_{50}$ ) and that of control are presented (Table.1 \& 2). The total, structural and soluble protein levels were found to decrease in fish exposed to Fenoxapro-P-Ethyl. This indicated the toxicity of Fenoxapro-P-Ethyl towards the fish.

Fishes are the touchiest group among aquatic life forms which are the bio-markers of aquatic contamination. The all out Fenoxapro-P-Ethyl levels in released scope of up to $37.5 \mu \mathrm{g} / \mathrm{L}$. This legitimizes the concentration of Fenoxapro-P-Ethyl considered for the current investigation. The organ liver is notable as a site of detoxification and because of its capacity, position and blood supply; it is additionally viewed as one of the organs generally influenced by impurities in the water Cohen P.P et al., 1960. It assumes a noticeable part in fish physiology, both in anabolism (protein, lipid, sugar) and catabolism (glycogenolysis, detoxification) and it goes about as capacity place for specific substances, particularly glycogen. It is liable for the balance of poisonous substances and metabolites to the less harmful structures. This breakdown is completed by endoplasmic reticulum of hepatocytes. Because of these reasons, even the hepatic cells all in all are harmed harshly. Consequently understanding the injury hit to the liver of fish exposed to Fenoxapro-P-Ethyl is a significant recommendation towards reestablishing environmental aquatic territory.

Numerous elements like proteins are associated with the reclamation of liver digestion Anusha Amali et al., 1996. Proteins are notable as building blocks of life and henceforth are mostly engaged with the structure of the cell Pandey.G 2013 and are the central wellspring of nitrogenous digestion. During the times of stress, proteins go about as a wellspring of energy. Decrease in protein levels was seen in the current investigation. The protein levels drained at 15 days was lesser than that of 30 days exposure. This part of our examination matches with the reports of Neelamegam et al., Lowry.O.H et al., 1951 who likewise cited that the exhaustion in protein levels of Cyprinus carpio upon exposure to toxicants are term subordinate.

During stress, fish need more energy to detoxify poisons and to defeat pressure; the protein is 
utilized to satisfy the increase energy need Baruah et al., 2004. The decrease in the aggregate, underlying and solvent proteins proposes the conceivable harm in the protein biosynthesis by sublethal concentration of Fenoxapro-P-Ethyl in the current investigation. Assessment of aggregate, underlying and dissolvable proteins was done and to have a more significant comprehension of the variety among primary, solvent and complete proteins were determined. Nonetheless, the net protein total was almost adjusted at the absolute protein level. Another report on abatement in protein levels by Fenoxapro-P-Ethyl forms are according to David et al., 2014 which is likewise in the kindness of the current examination. Essentially, reports of Anusha Amali et al., 1996, and Tilak et al., 2004, and Tilak et al., 2001 likewise bolsters the result of the current investigation. The reclamation of protein levels towards regularity demonstrates the versatile behaviour of fish in Fenoxapro-P-Ethyl free climate and to defeat the pressure by end of Fenoxapro-P-Ethyl segment from the body. This momentous capacity of the fish to bring back the protein levels towards the control is very much confirmed in the current investigation.

The report of increased movement of protease and rise in free amino acid levels (Table 2), it tends to be all around said that the height of free amino acids has a practical significance in order to satisfy energy needs and is additionally associated with osmoregulation. The increase in protease movement under pressure condition unmistakably proposes that Fenoxapro-P-Ethyl toxicity by inciting high protease action which prompts the arrangement of higher free amino acid substance causing hepatotoxicity. The increase in protease level is reflected as changes in catalyst movement that might be in reality because of Fenoxapro-P-Ethyl harming and indeed may go about as an early notice sign towards aquatic contamination Reitman, S. et al., 1957.

\section{Conclusion}

In view of the outcomes acquired from the current examination it is derived that Fenoxapro-PEthyl is toxic to the freshwater fish $C$. carpio even at a concentration of $37.5 \mu \mathrm{g} / \mathrm{L}$. It is proposed that sufficient consideration be taken to neutrilize and detoxify Fenoxapro-P-Ethyl before it is released into lakes and streams as it genuinely undermines the endurance of the present trial model.

\section{ACKNOWLEDGMENTS}

The authors thank the Department of Zoology Karnatak University PG Department of Studies in Zoology Karnatak University Dharwad for providing space for the animal maintenance.

\section{Conflicts of interest}

Authors claim no conflict of interest.

\section{REFERENCE}

- Amali, A. A., Kumar, L. C. A., Jayanthi, F. E., \& Selvanayagam, M. (1996). Quinalphos induced biochemical anomalies in Cirrhinus mrigala(Ham.). Journal of Environmental Biology, 17(2), 121-124.

- APHA. Standard Methods for the examination of water and waste water. 21st Ed. Washington D.C. (2005).

- $\quad$ Awasthi, M., Shah, P., Dubale, M. S., \& Gadhia, P. (1984). Metabolic changes induced by organophosphates in the piscine organs. Environmental research, 35(1), 320-325.

- Baruah, B. K., Sengupta, S., \& Das, M. (2004). Effect of Paper mill effluent of muscle protein profile of fish Heteropneustes fossilis (Bloch). Pollution Research, 23(4).

- Benitez, F. J., Real, F. J., Acero, J. L., \& Garcia, C. (2006). Photochemical oxidation processes for the elimination of phenyl-urea herbicides in waters. Journal of Hazardous Materials, 138(2), 278-287.

- Bradbury, S. P., McKim, J. M., \& Coats, J. R. (1987). Physiological response of rainbow trout (Salmo gairdneri) to acute fenvalerate intoxication. Pesticide Biochemistry and Physiology, 27(3), 275-288.

- Camargo, M. M., \& Martinez, C. B. (2007). Histopathology of gills, kidney and liver of a Neotropical fish caged in an urban stream. Neotropical Ichthyology, 5(3), 327-336.

- Chebbi, S. G., \& David, M. (2011). Modulation in the protein metabolism under sublethal concentration of Quinalphos intoxication in the freshwater common carp, Cyprinus carpio (Linnaeus, 1758). Int J Pharma Biol Arch, 2, 11831189.

- COHEN, P. P., \& BROWN JR, G. W. (1960). Ammonia metabolism and urea biosynthesis. Comparative biochemistry, 161-244.

- David, M., \& Lokeshkumar, P. (2020). Studies on carbosulfan induced oxygen deprivation and behavioral anomalies in fresh water fish cyprinus carpio. Journal of Advanced Scientific Research, 11(4 Suppl 9), 2021.

- David, M., Mushigeri, S. B., Shivakumar, R., \& Philip, G. H. (2004). Response of Cyprinus carpio (Linn) to sublethal concentration of cypermethrin: alterations in protein metabolic profiles. Chemosphere, 56(4), 347-352.

- Davis. N. C, E. L. Smith. 1955. Assay of proteolytic enzymes. Met. Biocem. Anal. 2, 215 257.

- Duncan, D. M. 1955. Multiple range and multiple tests. Biometrics, 42:1-4.

- Durairaj, S., \& Selvarajan, V. R. (1992). Influence of quinalphos, an organophosphorous pesticide, on the biochemical constituents of the tissues of fish, 
Oreochromis mossambicus. Journal of Environmental Biology, 13(3), 181-183.

- Ghosh, D., Bhattacharya, S., \& Mazumder, S. (2006). Perturbations in the catfish immune responses by arsenic: organ and cell specific effects. Comparative biochemistry and physiology part C: toxicology \& pharmacology, 143(4), 455463.

- Ghosh, T. K. (1989). Influence of cypermethrin on the oxidative metabolism of Labeo rohita. Proceedings of the Indian National Science Academy. Part B Biological sciences, 55(2), 115119.

- Glusczak, L., Loro, V. L., Pretto, A., Moraes, B. S., Raabe, A., Duarte, M. F., ... \& de Sousa Valladão, D. M. (2011). Acute exposure to glyphosate herbicide affects oxidative parameters in piava (Leporinus obtusidens). Archives of Environmental Contamination and Toxicology, 61(4), 624-630.

- Harper, H.A., 1979. In: Harper, H.A., Rodwell, V.W., Mayes, P.A. (Eds.), Review of Physiological Chemistry. Lange Medical Publications, California

- Hosetti, B. B., Dube, P. N., \& Shwetha, A. (2011). Metabolic changes in the freshwater fish Catla catla, under copper cyanide intoxication. International Journal of Pharmaceutical and Biological Archives, 2(3), 874-879.

- Humason, G. L. Animal tissue techniques. Pp- 64. 3rd Ed. W. H. Free-man and Co., SanFranc. (1972)

- Indirabai, W. P. S., Tharani, G. G., \& Seetha, P. (2010). Impact of sublethal concentration of endosulfan on biochemicals and histology of organ tissues of freshwater fish, Labeo rohita(Hamilton, 1822). Bioscan, 5(2), 215-218.

- Jebakumar, S. R. D., Flora, S. D. J., Ganesan, R. M., Jagatheesan, G., \& Jayaraman, J. (1990). Effect of short-term sublethal exposure of cypermethrin on the organic-constituents of the fresh-water fish lepidocephalichthys-thermalis. Journal

Environmental Biology, 11(2), 203-209.

- Jha, B. S., \& Verma, B. P. (2002). Effect of pesticidal mixture on protein content in the freshwater fish Clarias batrachus. Journal of Ecotoxicology and Environmental Monitoring, 12(3), 177-180.

- Lowenstein, J.M., Goodman, M.N., 1978. The purine nucleotide cycle in skeletal muscle. Fed. Proc. 37, 2308-2312.

- Lowry. O. H, Rosenbrough. N. J, Farr. A. L, Randall. R. J. Protein measurement with Folin phenol reagent. Journal of Biological Chemistry (1951)193: 265-275.

- M.C. Diez, Biological aspects involved in the degradation of organic pollutants, J. Soil. Sci. Plant Nutr. 10 (2010) 244-267.

- Mastan, S. A., \& Rammayya, P. J. (2010). Biochemical profile of Channa gachua (Ham) exposed to sublethal doses of Dichlorovas
(DDVP). The internet journal of Toxicology, 8(1), 27-32.

- Moore, S., \& Stein, W. H. (1954). A modified ninhydrin reagent for the photometric determination of amino acids and related compounds. Journal of Biological Chemistry, 211(2), 907-913.

- Moorthy, K. S., Reddy, B. K., Swami, K. S., \& Chetty, C. S. (1984). Changes in respiration and ionic content in tissues of freshwater mussel exposed to methyl parathion toxicity. Toxicology letters, 21(3), 287-291.

- Neelamegam, P., Rajendran, A., Maruthanayagam, C., \& Mohanraja, M. (2006). Study the protein variations induced by Monocrotophos in Cyprinus carpio using PIC16F877 microcontroller.

- $\quad$ Neglur, S. B., Sanakal, R. D., \& David, M. (2020). Studies on toxicological endpoints of fenoxapropp-ethyl on behavioral changes in freshwater exotic carp cyprinus carpio (linnaeus). Journal of Advanced Scientific Research, 11

- OECD. OECD Guidelines for Testing of Chemicals (No.203; Adopted: 17th July, 1992). (1992)

- Ogueji, E. O., \& Auta, J. (2007). Investigations of biochemical effects of acute concentrations of Lambda-cyhalothrin on African catfish, Clarias gariepinus-Teugels. J. Fish. Int, 2(1), 86-90.

- Palanichamy, S., Arunachalam, S., \& Baskaran, P. (1989). Effect of pesticides on protein metabolism in the freshwater catfish Mystus vittatus. Journal of Ecobiology, 1(2), 90-97.

- Pandey. G. Toxicity of cyanide in fishes: An overview, Universal Journal of Pharmacy. (2013) 02 (02):23-26.

- Patil, V. K., \& David, M. (2008). Behaviour and respiratory dysfunction as an index of malathion toxicity in the freshwater fish, Labeo rohita (Hamilton). Turkish Journal of fisheries and aquatic sciences, 8(2).

- Piska, R. S., Waghray, S., \& Devi, I. (1992). The effect of sublethal concentration of synthetic pyrethroid, cypermethrin to the common carp, Cyprinus carpio communis(Linnaeus) fry. Journal of Environmental Biology, 13(2), 89-94.

- Prasad, B. B., Singh, K. M., \& Rani, M. (2002). Dimethoate and monocil toxicity on the concentration of protein and amino acid in the serum and liver of Channa marulius(Ham.). Nature, Environment and Pollution Technology, 1(2), 147150.

- Prasad, D., \& Veeraiah, K. (2002). Effect of cypermethrin on protein metabolism of the fish, Labeo rohita (Hamilton). Bull. Pure Appl. Sci, 21(1), 27-32.

- Rafat Yasmees, M., 1986. Physiological responses of freshwater fish, Anabas scandens to the toxicity of Endosulfan. Doctoral Dissertation, Osmania University, Hyderabad, India 
- Rao. S, K. Sreenivasa, Murthy. K, Reddy. B, Swami. K. S, Sreeramulu. C. Effect of Benthicarb on Protein metabolism of freshwater teleost fish Sarotherodon mossambicus. Indian J. Environ. Health, (1987) 29: 45-15.

- Ravinder, V., Suryanarayana, N., \& Narayana, G. (1988). Decis induced biochemical alterations in a freshwater catfish, Clarias batrachus. Ind J Comp Anim Physiol, 6, 5-12.

- Rebich, R. A., Coupe, R. H., \& Thurman, E. M. (2004). Herbicide concentrations in the Mississippi River Basin - the importance of chloroacetanilide herbicide degradates. Science of the Total Environment, 321(1-3), 189-199.

- Reitman, S., Frankel, S., 1957. A colorimetric method for the determination of serum glutamic oxaloacetate and glutamic pyruvic transaminases. Amer. J. Clin. Pathol. 289, 56-63.

- Rossi, S. C., Da Silva, M. D., Piancini, L. D. S., Ribeiro, C. A. O., Cestari, M. M., \& de Assis, H. C. S. (2011). Sublethal effects of waterborne herbicides in tropical freshwater fish. Bulletin of environmental contamination and toxicology, 87(6), 603-607.

- RS, M., \& Shaikh, A. (2013). Effect of malathion toxicity on detoxifying organ of fresh water fish channa punctatus. International Journal of Pharmaceutical, Chemical \& Biological Sciences, 3(3).

- Sambasiva Rao, K.R.S., 1983. Impact of technical and commercial grade phenthoate on some selected parameters of oxidative metabolism in the fish, Channa punctatus. J. Environ. Biol. 8, 173-177.
- Sheela, M., Mathivanan, R., \& Muniandy, S. (1992). Impacts of fenvalerate on biochemical status of different tissues in the fish Channa striatus(Bloch). Environment and ecology. Kalyani, 10(3), 547-549.

- Srinivas, M. K., Reddy, B. K., Swami, K. S., \& Chetty, C. S. (1986). Effect of pesticide dichlorvos on succinate and malate dehydrogenases activity in fish, Sarotherodon mossambicus. Journal of Environmental Biology, 7, 101-6.

- Tilak, K. S., \& Rao, D. K. (2003). Chlorpyrifos toxicity of freshwater fish. J Aqua Biol, 8(2), 161166.

- Tilak, K. S., Veeraiah, K., \& Rao, D. K. (2005). Biochemical changes induced by chlorpyrifos, an organophosphate compound in sublethal concentrations to the freshwater fish Catla catla, Labeo rohita and Cirrhinus mrigala. Journal of environmental biology, 26(2 Suppl), 341-347.

- Velmurugan, B., Selvanayagam, M., Cengiz, E. I., \& Uysal, E. (2008). Levels of transaminases, alkaline phosphatase, and protein in tissues of Clarias gariepienus fingerlings exposed to sublethal concentrations of cadmium chloride. Environmental Toxicology: An International Journal, 23(6), 672-678.

- Yazgan, M. S., \& Tanik, A. (2005). A new approach for calculating the relative risk level of pesticides. Environment international, 31(5), 687692.

Yeragi, S. G., Koli, V. A., \& Yeragi, S. (2000). Effect of pesticide malathion on protein metabolism of the marine crab Uca marionis. Journal of Ecotoxicology \& Environmental Monitoring, 10(1), 59-62.

Cite This Article: Srinivas B Neglur, Rajeshwari D Sanakal, Muniswamy David (2022). Fenoxapro-P-Ethyl Induced Biochemical Changes in Fresh Water Fish Cyprinus carpio under Sublethal Exposure. East African Scholars J Agri Life Sci, 5(1), 1-9. 